\title{
PENGARUH KEPEMIMPINAN DAN DISIPLIN KERJA TERHADAP KINERJA KARYAWAN PADA PT CENTRAL CAPITAL FUTURES CABANG MALANG
}

\author{
ANY ISVANDIARI \\ Dosen STIE Asia Malang \\ BAGUS AL IDRIS \\ Alumni STIE Asia Malang
}

\begin{abstract}
Abstrak
Penelitian ini bertujuan untuk mengetahui : (1). Pengaruh kepemimpinan terhadap kinerja karyawan PT Central Capital Futures Cabang Malang; (2). Pengaruh disiplin kerja terhadap kinerja karyawan PT Central Capital Futures Cabang Malang; (3). Pengaruh kepemimpinan dan disiplin kerja secara simultan terhadap kinerja karyawan PT Central Capital Futures Cabang Malang. Metode penelitian adalah kuantitatif yang bersifat sebab akibat atau kausal dengan teknik analisis regresi linier berganda. Populasinya adalah seluruh karyawan yang berjumlah 37 karyawan dengan sampel 37 karyaan dengan menggunakan sampling penuh (sensus). Uji hipotesis menggunakan uji $t$ (partial) dan uji $F$ (simultan). Hasil uji t (partial) menunjukkan bahwa kepemimpinan berpengaruh positif dan signifikan terhadap kinerja karyawan, disiplin kerja berpengaruh positif dan signifikan terhadap kinerja karyawan; dan hasil uji $F$ (simultan) menunjukkan bahwa kepemimpinan dan disiplin kerja secara bersama-sama berpengaruh terhadap kinerja karyawan.
\end{abstract}

Kata kunci : kepemimpinan; disipil kerja; kinerja karyawan.

Abstrak:

This study aims to determine: (1). The influence of leadership on employee performance of PT Central Capital Futures Malang Branch; (2). The influence of work discipline on employee performance of PT Central Capital Futures Malang Branch; (3). The influence of leadership and work discipline simultaneously on employee performance of PT Central Capital Futures Malang Branch. The research method is quantitative causality or causal with multiple linear regression analysis technique. The population is all 37 employees with 37 samples using full sampling (census). Hypothesis test using t test (partial) and F test (simultaneous). The result of $t$ test (partial) shows that leadership has positive and significant effect to employee's performance, work discipline has positive and significant impact to employee's performance; and F test results (simultaneous) indicate that leadership and work discipline together effect on employee performance. Keywords: leadership; disipil work; employee performance.

\section{PENDAHULUAN}

Organisasi merupakan tempat berinteraksi dua orang atau lebih yang di dalamnya terdapat hubungan antara pimpinan dan bawahan. Organisasi merupakan kesatuan sosial yang dikoordinasikan secara sadar dengan sebuah batasan yang reaktif dapat diidentifikasikan, bekerja secara terus-menerus untuk mencapai tujuan (Robbins, 2006).

Perusahaan sebagai salat satu bentuk sebuah organisasi tidak mungkin terlepas dari tenaga kerja manusia, walaupun aktivitas perusahaan tersebut telah mempunyai modal cukup besar dan teknologi modern, sebab bagaimanapun majunya teknologi tanpa ditunjang oleh manusia sebagai sumber dayanya maka tujuan perusahaan tidak akan tercapai. Sumber daya yang dimaksud adalah sumber daya manusia, ialah orang-orang yang memberikan tenaga, pikiran, bakat, kreativitas dan usahanya pada perusahaan, dengan harapan bahwa suatu saat perusahaan akan mengalami perkembangan yang pesat di dalam lingkup usaha dari perusahaannya dan menginginkan kinerja yang baik dalam bidang pekerjaannya.

Menurut Bachmasari (2009) kinerja adalah pencapaian atas tujuan organisasi yang dapat berbentuk output kuantitatif, kreativias, fleksibilitas, dapat diandalkan atau hal-hal lain yang diinginkan organisasi. Menurut Moehirono (2012: 95) kinerja merupakan gambaran mengenai tingkat pencapaian pelaksanaan suatu program kegiatan atau kebijakan dalam mewujudkan sasaran, tujuan, visi dan misi organisasi yang dituangkan melalui perencanaan strategis suatu organisasi. Demi tercapainya tujuan yang telah ditetapkan perusahaan (organisasi) setiap perusahaan akan berusaha untuk selalu meningkatkan kinerja karyawannya dengan cara mewujudkan kepuasan kerja di antaranya melalui gaya kepemimpinan dan disiplin kerja yang sesuai dengan harapan karyawannya.

Seorang pemimpin adalah orang yang memberi inspirasi, membujuk, mempengaruhi dan memotivasi kerja orang lain. Perananseorang pemimpin dalam suatu organisasi sangat dominan, tetapi walaupun demikian seorang pemimpin tidak boleh mengabaikan pentingnya peranan para tenaga kerja atau karyawan. Seorang pemimpin harus bisa mengubah pikiran bawahannya atau bertindak tegas ( Dubrin, 2006 : 10-11).

Mangkuprawira $\quad(2017 \quad: \quad 122)$ mendefinisikan disiplin kerja adalah sifat seseorang 
karyawan yang secara sadar mematuhi aturan dan peraturan organisasi tertentu. Disiplin kerja merupakan kegiatan dari manajemen perusahaan yang brfungsi sebagai bentuk pengendalian karyawan dalam menjalankan standard organisasi di perusahaan yang teratur demi tercapainya sasaran atau tujuan perusahaan.

PT Central Capital Futures merupakan salah satu perusahaan pialang berjangka di Indonesia bertaraf internasional yang memberikan pelayanan maksimal dalam bertransaksi valuta asing, indeks saham dan komoditi berjangka da berkantor pusat di Jakarta, serta memiliki beberapa kantor cabang antara lain di Medan, Surabaya, Semarang, Bandung, Banjarmasin, Yogyakarta, Pekanbaru, Purwokerto dan Malant. Penelitian ini difokuskan pada karyawan PT Central Capital Futures Cabang Malang Jawa Timur. Permasalahan yang ada pada PT Central Capital Futures Cabang Malang adalah menurunnya kinerja dari karyawan disebabkan karena gaya kepemimpinan dan kurangnya disiplin kerja dari karyawannya.

\section{Rumusan Masalah}

Berdasarkan latar belakang di atas, maka rumusan masalah dalam penelitian ini adalah : (1). Apakah kepemimpinan berpengaruh terhadap kinerja karyawan PT Central Capital Futures Cabang Malang?; (2). Apakah disiplin kerja berpengaruh terhadap kinerja karyawan PT Central Capital Futures Cabang Malang?; (3). Apakah kepemimpinan dan disiplin kerja berpengaruh secara simultan terhadap kinerja karyawan PT Central Capital Futures Cabang Malang?

\section{Landasan Teori}

Kepemimpinan

Kepemimpinan merupakan faktor yang sangat penting dalam mempengaruhi hasil kinerja perusahaan, sebab kepemimpinan merupakan aktivitas utama yang berhubungan dalam pencapaian tujuan organisasi atau perusahaan. Dalam Gitosudarmo (2000 : 127) kepemimpinan didefinisikan sebagai suatu proses mempengaruhi aktivitas dari individu atau kelompok. Sedangkan dalam Ivancevich (2007 : 194) kepemimpinan diartikan sebagai proses mempengaruhi orang lain untuk mendukung pencapaian tujuan organisasi yang relevan. Menurut Kartono (2008 : 34) menyatakan, bahwa kepemimpinan adalah sifat, kebiasaan, temperamen, watak dan kepribadian yang membedakan seorang pemimpin dalam berinteraksi dengan orang lain.

Syarat-syarat kepemimpinan menurut Kartono (2008: 36) ada 3 hal, yaitu : 1). Kekuasaan : adalah kekuatan, otorita dan legalitas yang memberikan wewenang kepeda pemimpin guna mempengaruhi dan menggerakkan bawahan untuk berbuat sesuatu. 2). Kewibawaan adalah kelebihan, keunggulan, keutamaan sehingga orang mampu mengatur orang lain, agar orang tersebut patuh pada pemimpin dan bersedia melakukan perbuatan-perbuatan tertentu. 3). Kemampuan ialah segala daya, kesanggupan, kekuatan dan kecakapan atau ketrampilan teknis maupun sosial yang dianggap melebihi dari kemampuan anggota biasa.

Menurut Stephen Covey dalam Antonio (2007 : 20) menekankan bahwa seorang pemimpin harus memiliki empat fungsi kepemimpinan, yaitu sebagai : 1). perintis; 2). penyelaras; 3). pemberdaya dan 4). panutan.

\section{Indikator Kepemimpinan}

Indikator kepemimpinan menurut

Kartono (2008 : 34) menyatakan sebagai berikut : 1). Sifat : sifat seorang pemimpin sngat berpengaruh dalam gaya kepemimpinan untuk menentukan keberhasilan menjadi seorang pemimpin yang berhasil, serta ditentukan oleh kemampuan pribadi pemimpin., 2). Kebiasaan : kebiasaan memegang peranan kepemimpinan sebagai penentu pergerakan perilaku seorang pemimpin yang menggambarkan segala tindakan yang dilakukan sebagai pemimpin yang baik., 3). Temperamen : adalah gaya perilaku yang cara khasnya dalam memberi tanggapan dalam berinteraksi dengan orang lain., 4). Watak : Watak seorang pemimpin yang lebih subyektif dapat menjadi penentu bagi keunggulan seorang pemimpin dalam mempengaruhi keyakinan, ketekunan, daya tahan dan keberanian., 5). Kepribadian : kepribadian seorang pemimpin menentukan keberhasilannya yang ditentukan oleh sifat-sifat atau karakteristik kepribadian yang dimilikinya.

\section{Disiplin Kerja}

Menurut Wardana (2008 : 20) disiplin kerja merupakan upaya pengaturan waktu dalam bekerja yang dilakukan secara teratur dengan mengembangkan dan mengikuti aturan kerja yang ada. Sedang menurut Hasibuan (2008 : 444) berpendapat bahwa kedisiplinan adalah kesadaran dan kesediaan seseorang menaati semua peraturan perusahaan dan norma-norma sosial yang berlaku. Dengan demikian yang dimaksud dengan disiplin kerja adalah merupakan suatu sikap, tingkah laku dan perbuatan yang sesuai dengan peraturan baik tertulis maupun tidak tertulis dan bila melanggar akan ada sanksi atas pelanggarannya.

Indikator Disiplin Kerja

Menurut H. Melayu Hasibuan (2008 : 194) pada dasarnya banyak indikator yang mempengaruhi tingkat kedisiplinan seorang karyawan, di antaranya : 1). tujuan dan kemampuan : tujuan yang akan dicapai harus jelas dan ditetapkan secara ideal serta cukup menantang bagi kemampuan karyawan. 2). Terhadap pimpinan : teladan pimpinan sangat berperan dalam menentukan kedisiplinan karyawan, karena 
pimpinan dijadikan teladan dan panutan oleh para bawahannya. 3). Balas jas : balas jasa (gaji dan kesejahteraan) turut mempengaruhi kedisiplinan karyawan karena balas jasa akan memberikan kepuasan dan kecintaan karyawan terhadap perusahaan dan pekerjaannya. 4). Keadilan : keadilan turut mendorong terwujudnya kedisiplinan karyawan. 5). Ketegasan : ketegasan pimpinan dalam melakukan tindakan akan mempengaruhi kedisiplinan karyawan.

\section{Kinerja Karyawan}

Menurut Sedarmayanti (2011 : 260) lonerja merupakan terjemahan dari performance yang berarti hasil kerja seorang pekerja. Sedangkan menurut Mangkunegara (2009 : 67) kinerja adalah hasil kerja secara kualitas dan kuantitas yang dicapai oleh seorang karyawan dalam melaksanakan tugasnya sesuai dengan tanggung jawab yang diberikan.

\section{Indikator Kinerja}

Menurut Mangkunegara (2009 : 75) mengemukakan, bahwa indikator kinerja yaitu : 1). Kualitas : adalah seberapa baik seorang karyawan mengerjakan apa yang seharusnya dikerjakan. 2). Kuantitas : adalah seberapa lama seorang karyawan bekerja dalan satu harinya. Kuantitas kerja ini dapat dilihat dari kecepatan kerja dari masingmasing karyawan. 3). Pelaksanaan tugas : adalah seberapa jauh karyawan mampu melakukan pekerjaannya dengan akurat atau tidak ada kesalahan. 4). Tanggung jawah : terhadap pekerjaan adalah kesadaran akan kewajiban karyawan untuk melaksanakan pekerjaan yang diberikan perusahaan.

\section{Kerangka Konseptual dan Perumusan Hypotesis.}

Berdasarjab perumusan masalah, tjuan penelitian dan landasan teori, maka kerangka konseptual penelitian dapat dilihat pada Gambar 1.

Gambar 1 Kerangka konseptual :

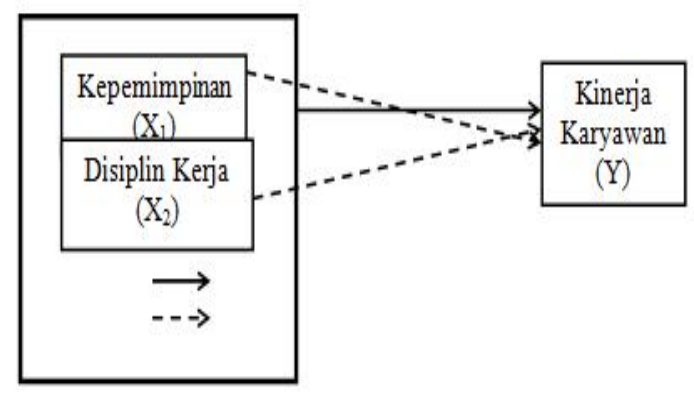

Berdasarkan kerangka konseptual pada gambar 1 di atas maka rumusan hipotesis penelitian sebagai berikut :
$\mathrm{H}_{1}$ : Diduga ada pengaruh kepemimpinan terhadap kinerja karyawan pada PT Central Capital Futures Cabang Malang.

$\mathrm{H}_{2}$ : Diduga ada pengaruh Disiplin Kerja terhadap kinerja karyawan pada PT Central Capital Futures Cabang Malang.

$\mathrm{H}_{3}$ : Diduga ada pengaruh secara simultan kepemimpiinan dan disiplin kerja terhadap kinerja karyawan pada PT Central Capital Futures Cabang Malang.

\section{METODOLOGI PENELITIAN}

Populasi dan Teknik Pengambilan Sampel Populasi dalam penelitian ini adalah seluruh karyawan pada PT Central Capital Futures Cabang Malang yang berjumlah 37 orang tidak termasuk pimpinan yang berjumlah 1 orang.

Dalam teknik pengambilan sampel penelitian ini menggunakan teknik sampling penuh. Sampling penuh adalah teknik penentuan sampel apabila semua anggota populasi digunakan sebagai sampel. (Sugiono, 2009 : 96). Karena jumlah populasi kurang dari 100 orang, maka yang menjadi smpel adalah karyawan PT Central Capital Futures Cabang Malang yang berjumlah 37 orang.

\section{Definisi Operasional Variabel}

Definisi operasional variabel dalam penelitian ini dapat dijelaskan sebagi berikut :

Variabel Kepemimpinan dengan indikator sebagai berikut: 1). Sifat, 2). Kebiasaan 3). Temperamen, 4). Watak, 5). Kepribadian

Variabel Disipin kerja dengan indikator sebagai berikut 1). Tujuan dn kemampuan, 2). Teladan pimpinan. 3). Balas jasa. 4). Keadilan dan 5). Ketegasan

Variabel Kinerja Karyawan dengan indicator sebagai berikut: 1). Kualitas, 2). Kuantitas, 3). Pelaksanaan Tugas dan 4). Tanggung jawab

\section{ANALISIS DATA}

Teknik analisis yang digunakan untuk mengetahui seberapa besar pengaruh variabel bebas terhadap variabel terikat yaitu dengan analisis regresi linier berganda dengan rumus persamaan regresi sebagai berikut:

$\mathrm{Y}=\mathrm{a}+\mathrm{b}_{1} \mathrm{X}_{1}+\mathrm{b}_{2} \mathrm{X}_{2}+\mathrm{e}$

Untuk menguji secara partial antara kepemimpinan dan disipilin kerja terhadap kinerja karyawan PT Central Capital Futures Cabang Malang digunakan uji t. Dengan membandingkan antara $t_{\text {tabel }}$ dan $t_{\text {hitung }}$ dan melihat tingkat signifikan $(\alpha)$ sebesar $5 \%$ dan $\mathrm{d} f=(\mathrm{n}-1)$ apabila $\mathrm{t}_{\text {hitung }}>\mathrm{t}_{\text {tabel }}$ maka $\mathrm{H}_{0}$ diterima dan $\mathrm{H}_{\mathrm{a}}$ diterima (tidak berpengaruh signifikan).

Sedangkan untuk menguji secara simultan antara variabel kepemimpinan dan disiplin kerja terhadap kinerja karyawan PT Central Capi8tal Futures Cabang Malang menggunakan uji F. $F_{\text {tabel }}$ 
ditentukan dengan melihat tingkat signifikan sebesar $5 \%$ dan $\mathrm{d} f=(\mathrm{n}-1)$, jika hasilnya $\mathrm{F}_{\text {hitung }}>$ $\mathrm{F}_{\text {tabel }}$ maka $\mathrm{H}_{0}$ ditolak dan $\mathrm{H}_{\mathrm{a}}$ diterima (berpengaruh signifikan) dan bila $\mathrm{F}_{\text {hitung }}<\mathrm{F}_{\text {tabel }}$ maka $\mathrm{H}_{0}$ diterima dan $\mathrm{H}_{\mathrm{a}}$ ditolak (tidak berpengaruh signifikan).

\section{HASIL DAN PEMBAHASAN}

Analisis Deskriptif

1. Deskripsi jawaban responden dari variabel kepemimpinan $\left(\mathrm{X}_{1}\right)$

Berdasarkan data yang terkumpul dari kuestioner tentang variabel kepemimpinan, $62 \%$ responden setuju dengan item-item pernyataan mengenai pimpinan mempunyai kepribadian yang menyenangkan; pmpinan selalu menorong karyawan untuk meningkatkan kinerja; pimpinan selalu hadir tepat waktu; pimpinan menghargai dan memuji karyawan yang kinerjanya bagus; pimpinan sering menekankan pentingnya tegas; pimpinan mempengaruhi cara pandang karyawan untuk menyelesaikan pekerjaan; pimpinan menghormati gagasan karyawan yang ingin menyempaikan ide-ide tentang pekerjaannya.

2. Deskripsi jawaban responden dari variabel Disiplin Kerja $\left(\mathrm{X}_{2}\right)$

Berdasarkan data yang terkumpul dari kuestioner tentang vvariabel disiplin kerja, $63 \%$ responden menyatakan setuju dengan item-item pernyataan bahwa karyawan tidak selalu menyelesaikan pekerjaan sesuai dengan prosedur perusahaan; pimpinan memberikan contoh semangat kerja yang tinggi; bahwa insentif yang diterima karyawan sudah sesuai standard; bonus yang diterima sudah sesuai standard; bahwa karyawan selalu mematuhi aturan yang dibuat oleh perusahaan; pimpinan menegur setiap karyawan yang melanggar aturan.

3. Deskripsi jawaban responden dari Variabel Kinerja Karyawan (Y).

Berdasarkan data yang terkumpul dari kuestioner tentang variabel kinerja karyawan, $54 \%$ responden menyatakan setuju dengan item-item pernyataan, bahwa karyawan mampu menyelesaikan pekerjaan melebihi standard yang ditetapkan; mempunyai etos kerja yang tinggi; selalu tepat waktu dalam menyelesaikan pekerjaan; mampu malaksanakan pekerjaan dengan baik; berusaha bekerja lebih keras dari karyawan lain dlam menyelesaikan pekerjaan; mempunyai komitmen dan tanggung jawab dalam bekerja.

\section{ANALISIS REGRESI LINIER BERGANDA DAN PENGUJIAN HIPOTESIS}

Tabel berikut adalah hasil perhitungan dari regresi linier berganda dengan bantuan SPSS for Windows versi 23

Tabel 1. Hasil Analisis Regrasi Linier Berganda

\begin{tabular}{|c|c|c|c|c|c|c|c|}
\hline \multicolumn{8}{|c|}{ Cosficiens? } \\
\hline \multirow{2}{*}{ Uodel } & \multicolumn{2}{|c|}{$\begin{array}{l}\text { Cnstacradized } \\
\text { Coeficieris }\end{array}$} & \multirow{2}{*}{$\begin{array}{l}\text { Strdarcized } \\
\text { Coefficiels } \\
\text { Bete }\end{array}$} & \multirow[b]{2}{*}{$t$} & \multirow[b]{2}{*}{ Sig. } & \multicolumn{2}{|c|}{$\begin{array}{l}\text { Collineatly } \\
\text { Stetisics }\end{array}$} \\
\hline & $\bar{B}$ & $\begin{array}{l}\text { Std } \\
\text { Etret }\end{array}$ & & & & Toleance & VIF \\
\hline 1(Constant) & 1,282 & $4,0]$ & &, $45 j$ & .62 & & \\
\hline Yonaning & 425 & , J33 & 601 & 5094 &, 000 & 908 & 1,002 \\
\hline Dispir kera & $45 ?$ & 124 & 425 & 3,694 &, 01 & 908 & 1,00 \\
\hline
\end{tabular}

Sumber: Data diolah (2017)

Dari hasil analisis persamaan regresi tersebut, dapat disusun persamaan regresi :

$\mathrm{Y}=1,823+0,425 \mathrm{X}_{1}+0,457 \mathrm{X}_{2}+4,008$

Dari Tabel 2 di atas, dapat dilihat bahwa besarnya koefisien untuk kepemimpinan sebesar 0,425 dan arahnya positif. Hal ini mempunyai arti apabila pimpinan meningkatkan kepemimpinannya maka kenerja karyawan akan meningkat sebesar $42,5 \%$. Sedangkan koefisien untuk disiplin kerja sebesar 0, 457 dan arahnya positif; yang mempunyai arti apabila disiplin kerja naik $1 \%$ maka kinerja karyawan naik sebesar $45,7 \%$.

Sedangkan untuk pengujian secara parsial juga dapat dilihat pada Tabel 2 yang menunjukkan nilai $t_{\text {hitung }}$ untuk variabel kepemimpinan $\left(\mathrm{X}_{1}\right)$ adalah 5,094 $>\mathrm{t}_{\text {tabel }}$ 1,6909 dan Sig. 0,000 > Sig. 0,05. Hal ini dapat simpulkan bahwa kepemimpinan berpengaruh positif dan signifikan terhadap kinerja karyawan PT Central Capital Futures Cabang Malang.

Selanjutnya pengujian secara parsial pada variabel disiplin kerja (X2) terhadap kinerja karyawan menunjukkan thitung 3,694>ttabel 1,6909 dan Sig. 0,000 > Sig. 0,05 sehingga dapat disimpulkan bahwa variabel disiplin kerja berpengaruh positif dan signifikan teradap kinerja karyawan PT Central Capital Futures Cabang Malang.

Sementara itu, pengujian secara simultan dapat dilihat pada Tabel di bawah ini

Tabel 2, Uji F

\begin{tabular}{|c|c|c|c|c|c|}
\hline & \multicolumn{5}{|c|}{$\triangle \mathrm{NOH}^{2}$} \\
\hline & Sum of & & Mean & & \\
\hline Model & Sguares & $d f$ & Solare & $\mathrm{F}$ & Sig. \\
\hline 1Regrsion & 112,961 & 2 & 36,480 & 18,986 &, $000^{2}$ \\
\hline Resitoual & $101,14 ?$ & 34 & 2.975 & & \\
\hline Total & 214,108 & 36 & & & \\
\hline
\end{tabular}

a. Dependent Variable: Kinerja

b. Predictors: (Constant): Disiolin Kerja, Kevemimpinen

Sumber : data primer diolah (2017) 
Pada tabel 3 menunjukkan $\mathrm{F}_{\text {hitung }}$ sebesar 18,986 dengan Sig. $F=0,000$ dan $F_{\text {tabel }}=4,12$ sehingga dapat ditarik kesimpulan $\mathrm{F}_{\text {hitung }}>\mathrm{F}_{\text {tabel }}$ dengan demikian dapat dikatakan bahwa secara simultan kepemimpinan dan disiplin kerja berpengaruh positif dan signifikan terhadap kinerja karyawan PT Central Capital Futures Cabang Malang.

Uji determinan Adjusted $\mathrm{R}^{2}$ adalah untuk mengukur seberapa jauh kemampuan variabel bebas dalam menerangkan variasi varibel terikaat. Untuk mengukur berapa tingkat pengaruh variabel bebas ke vabriabel terikat dapat dilihat pada tabel 4.

Tabel 3. Hasil Uji Koefisien Determinasi Adjusted $\mathrm{R}^{2}$

Moilel Sinnunaryt

\begin{tabular}{|c|c|ccc|}
\hline Model & $R$ & R Square & $\begin{array}{c}\text { Adjusted R } \\
\text { Square }\end{array}$ & $\begin{array}{c}\text { Std. Error of } \\
\text { the Estimate }\end{array}$ \\
\hline 1 &, $726^{\mathrm{a}}$ & 528 &, 500 & 1,72480 \\
\hline a. Predictors : (Constant): Disiplin Kerja, Kepemimpinan \\
b. Dependent Variable: Kinerja
\end{tabular}

Sumber : Data primer diolah (2017)

Dari tabel di atas dapat disimpulkan koefisien determinan $\left(\mathrm{R}^{2}\right)$ adalah 0,528 atau 52,8\% artinya sumbangan variabel kepemimpinan dan disiplin kerja terhadap variabel kinerja karyawan PT Central Capital Futures Cabang Malang sebesar $52,8 \%$ sedangkan sisanya yaitu sebesar $47,2 \%$ dipengaruhi oleh variabel lain yang tidak dibahas dalam penelitian ini.

\section{PEMBAHASAN}

Berdasarkan hasil analisis regresi linier berganda dan uji secara simultan diperoleh hasil bahwa kepemimpinan dan disiplin kerja berpengaruh terhadap kinerja karyawan PT Central Capital Futures Cabang Malang. Hal ini dapat dijelaskan bahwa untuk meningkatkan kinerja karyawan perlu mempertahankan kepemimpinan selama ini dan bila perlu ditingktatkan model kepemimpinan yang sudah dijalankan. Demikian halnya dengan variabel disiplin kerja perlu pula ditingkatkan agar kinerja karyawannya miningkat. Hal tersebut didukung oleh penelitian dari Adi Nugroho (2015); Aryo Nimpuno (2015) dan Fenny Dwi Oktavia (2014) yang menemukan bahwa kepemimpinan dan disiplin kerja mempunyai pengaruh terhadap kinerja karyawan. Artinya apabila penerapan disiplin kerja dan kepemimpinan dapat berjalan baik maka akan meningkatkan kinerja karyawan PT Central Capital Futures Cabang Malang.

Sementara apabila dianalisis secara partial pengaruh variabel kepemimpinan terhadap kinerja karyawan dari hasil perhitungan uji $t$ dapat disimpulkan variabel kepemimpinan berpengaruh positif dan signifikan terhadap kinerja karyawan PT Central Capital Futures Cabang Malang. Hal ini disebabkan karena kepemimpinan yang diterapkan pata PT Central Capital Futures Cabang Malang diterima dengan baik oleh karyawan dilihat dari sebagian besar tanggapan kuesioner yang menjawab sangat setuju dan setuju.

Penelitian ini mendukung teori Bangun (2012 : 339 - 340) yang menyatakan kepemimpinan merupakan slah satu fungsi manajemen yang dilakukan untuk mewujudkan visi orgnisasi. Keberhasilan manajer dalam mempengaruhi para anggotanya terlihat dari kepatuhan dan ketaatan para pengikutnya atas rasa tanggung jawab pekerjaannya. Manajer yang berhasil melaksanakan tugas kepemimpinannya dapat menumbuhkan rasa semangat kerja para anggotanya yang berakibat pada meningkatnya kinerja.

Semetara variabel disiplin kerja pengaruhnya secara parsial terhadap kinerja karyawan hasil perhitungan dari uji t menunjukkan, bahwa berpengaruh positif dan signifikan. Penelitian ini mendukung penelitian yang dilakukan oleh Nimpuno (2015) yang hasil penelitiannya menunjukkan bahwa disiplin kerja berpengaruh positif dan signifikan terhadap kinerja karyawan; sera mendukung teori Rivai (2011 : 825) yang mnyatakan disiplin kerja adalah suatu alat yang digunakan para manajer untuk berkomunikasi dengan karyawan agar mereka bersedia untuk mengubah suatu perilaku serta sebagai suatu upaya untuk meningkatkan kesadaran dan kesediaan seseorang menaati semua peraturan perusahaan dan norma-norma sosial yang berlaku.

\section{KESIMPUAN DAN SARAN \\ Kesimpulan}

Berdasarkan hasil analisis dan pembahasan penelitian ini maka dapat diambil kesimpulan sebagai berikut :

1. Kepemimpinan secara parsial berpengaruh positif dan signifikan terhadap kinerja karyawan.

2. Disiplin kerja secara parsial berpengaruh positif dan signifikan terhadap kinerja karyawan.

3. Kepemimpinan dan disiplin kerja secara simultasn berpengaruh positif dan signifikan terhadap kinerja karyawan.

\section{SARAN}

Berdasarkan pembahasan dan kesimpulan di atas, maka saran yang dapat diberikan antara lain :

1. Kepemimpinan yang dirasakan karyawan terbukti memberikan pengaruh terhadap kinerja karyawan secara positif dan signifikan, oleh karenanya perusahaan harus mempertahankan serta meningkatkan kepemimpinan yang lebih baik lagi guna 
menunjang kegiatan operasional perusahaan yang lebih optimal.

2. Disiplin kerja memberikan upaya pimpinan untuk memperhatikan hal-hal yang berkaitan dengan disiplin kerja karyawan agar karyawan mampu menyelesaiikan pekerjaan tepat waktu sesuai dengan yang diharapkan pimpinan.

\section{DAFTAR PUSTAKA}

1. Arikunto, S., 2010 "Prosedur Penelitian : Suatu Pendekatan Praktik", Edisi Revisi, Jakarta : Rineka Cipta.

2. Antonio S, 2007, "Bank Syariah dari Teori ke Praktik", Jakarta (ID) : Gema Insani Press.

3. Anwar Prabu Mangkunegara, 2007 : "Manajemen Sumber Daya Manusia", Cetakan ke tujuh, PT Remaja Rosdakarya, Bandung.

4. Cahyo Adinugroho, 2015, "Pengaruh Kepemimpinan dan Disiplin Kerja terhadap Kinerja Pegawai pada Dinas Pendidikan Kota Bengkulu, Universitas Negeri Jakarta.

5. Dubrin, Andrew J., 2006, "Leadership" (Terjemahan), Edisi Ketiga, Prenada Media : Jakarta.

6. Fatika Muti Wardani, 2015, "Pengaruh Gaya Kepemimpinan dan Disiplin Kerja terhadap Kinerja Karyawan (Studi pada PT Telekomunikasi Indonesia, Tbk Kandatel Malang, Sekolah Tinggi Ekonomi Asia Malang.

7. Fenny Dwi Oktavia, 2014 : "Pengaruh Kepemimpinan dan Disiplin Kerja terhadap Kierja Pegawai pada Dinas Pendidikan Kota Bengkulu, Universitas Bengkulu.

8. Galih Aryo Nimpuno, 2015, "Pengaruh Disiplin Kerja dan Kepemimpinan terhadap Kinerja Karyawan pad UD Pustaka Pelajar Yogyakarta, Universitas Negeri Yogyakarta

9. Ghozali Imam, 2009, “Aplikasi Analisis Multi8variate dengan Program SPSS”, Cetakan Keempat, Semarang, Badan Penerbit Universitas Diponegoro.

10. Gito Sudarma, Sudita, 2000, "Perilaku Keroganisasian”, Edisi Pertama BPFE, Jogyakarta.

11. Hasibuan, Malayu S.P. 2008, "Manajemen Sumber Daya Manusia", Jakarta : Penerbit Bumi Aksara, Ghozali.

12. Karono, Kartii, 2008 : "Pemimpin dan Kepemimpinan”, Jakarta : PT Raja Grafindo Persada.

13. Mangkunegara, AP., 2001 "Manajemen Sumber Daya Manusia Perusahaan", Edisi Baru, Remaja Resda Karya Bandung.

14. Mathis, Robert L. dan Jacson, 2011 : "Manajemen Sumber Daya Manusia" Edisi 9, Jakarta : Salemba Empat.

15. Regina Aditya Reza, 2015 : "Pengaruh Gaya Kepemimpinan, Motivasi dan Disiplin Kerja terhadap Kinerja Karyawan Studi pada PT Sinar
Santosa Perkasa Banjarnegara”, Ubiversitas Diponegoro Semarang.

16. Robbin, Stephen P., 2006 : "Perilaku Organisasi”, Edisi ke sepuluh, Jakarta : PT Indeks Kelompok Gramedia.

17. Sedarmayanti, 2011, “ Manajemen Sumber Daya Manusia, Reformasi Birokrasi dan Manajemen Pegawai Negeri Sipil", Cetakan Ke Lima, Bandung, : PT Refika Aditama.

18. Singarimbun, Masri dan Sofian Effendi, 2006, "Metode Penelitian Survei (Editor)", LP3ES, Jakarta.

19. Sugiyono, 2009, "Metode Penelitian Bisnis (Pendekatan Kuantitatif; Kualitatif dan R \& D)", Bandung, Alfabeta.

20. Veithzal Rivai, 2011, "Manajemen Sumber Daya Manusia untuk Perusahaan dari Teori ke Praktik, pt Raja Grafindo, Jakarta.

21. Wardana, 2008, "Meningkatkan Kinerja Melalui Evaluasi dan Coaching”, Medical Reps. 